\title{
A mobile genetic element in Serratia marcescens, a causative agent of onion disease
}

\author{
L. P. Ovcharenko, T. M. Voznyuk, I. E. Zaetz, A. I. Potopalsky, \\ O. Reva ${ }^{1,2}$, N. O. Kozyrovska
}

Institute of Molecular Biology and Genetics NAS of Ukraine 150, Akademika Zabolotnogo str., Kyiv, Ukraine, 03680

${ }^{1}$ Institute of Microbiology and Virology NAS of Ukraine 154, Akademika Zabolotnogo str., Kyiv, Ukraine, 03680

${ }^{2}$ University of Pretoria

Pretoria, South Africa

kozyr@imbg.org.ua

\begin{abstract}
Aim. To screen mobile genetic elements (MGE) in the bacterium which caused decay of field-grown onion bulb and to study an integron and gene cassettes associated. Methods. Polymerase chain reaction (PCR) and PCR products sequencing were used for both the bacterium and MGE identification. Terminally-labeled Restriction Fragment Length Polymorphism (TRFLP) analysis was performed for detection of any bacterium in the onion bulb tissue. Results. The bacterium, which caused field-grown onion decay, was identified by nucleotide sequence analysis of the $16 S$ rRNA genes to be S. marcescens known as phytopathogen. However, this isolate did not respond to specific primers designed for pathogenic strains. Inoculation of onion (Allium cepa L.), Arabidopsis thaliana (L.) Heyhn, and lettuce (Lactuca sativa) seeds resulted in biomass promotion of symptomless plants. PCR revealed the presence of a class 1 integron in S. marcescens $I M B G 291$ which represents the first isolation of this integron in phytopathogenic Serratia species. The gene cassettes harbored by the integron have been represented with the promoterless genes encoded formiminoglutamate deiminase and ascorbate-specific phosphotransferase system enzyme IIC, and with additional three senseless sequences flanked by a 59-bp element. Conclusion. S. marcescens IMBG291 exhibited plant growth promotion or pathogenicity, depending on the environmental situation, due to horizontally acquired new gene cassettes located in the integron.
\end{abstract}

Keywords: Serratia marcescens, onion disease, integron, gene cassettes.

Introduction. Onion bulb decay is caused by several opportunistic and pathogenic bacteria as Pseudomonas allicola, Burkholderia cepacia, S. marcescens [1,2]. $S$. marcescens is a gram-negative bacillus commonly isolated from the environment (soil, water, plants, insects) [3]. The cosmopolitan bacterium $S$. marcescens

(C) Institute of Molecular Biology and Genetics NAS of Ukraine, 2010 is represented as red-pigmented or nonpigmented strains, and it is known as a bacterium which exhibits either saprophytic or pathogenic characteristics. Plant growth promotion is a traditional attribute of $S$. marcescens [4] which also known as a plant endophyte [3]. S. marcescens induces systemic resistance in Arabidopsis plants against Cucumber mosaic virus [5] and abiotic stressors [6]. 
On the other hand, S. marcescens is etiological agent of white pox in elkhorn coral [7], the bugtransmitted cucurbit and yellow vine disease [8]. Disease-associated $S$. marcescens strains are significantly different from those of nonphytopathogenic strains [2].

$S$. marcescens is also known as an opportunistic pathogen which is responsible for an increasing number of serious nosocomial infections and colonization of hospital wards [9]. Antibiotic resistance in S. marcescens is coded by genes which often located in plasmids and integrons [10]. The purpose of this study was to characterize mobile genetic elements of a causative agent of onion decay isolated in South of Ukraine.

Materials and methods. Isolation of bacteria. The isolate IMBG291 is generated from the onion bulbs (Allium cepa L.), showing apparent symptoms of disease. Onion bulbs were gathered in Kherson region (Ukraine) in summer of 2007. Decaying leaf bases were minced at aseptic conditions, diluted with $0.9 \% \mathrm{NaCl}$ solution, spread on a surface on LB and M9 [11] agar plates and incubated at 28,37 and $42{ }^{\circ} \mathrm{C} 24 \mathrm{~h}$.

Bacterial strains and culturing bacteria. The strains of $S$. marcescens from other econiches were obtained from Institute of Infectious Diseases (Kyiv) and Taras Shevchenko Kyiv National University (U82 and $\mathrm{KGU}$, respectively) and used in experiments as reference. Escherichia coli DHB10 was used as recipient of recombinant plasmids in cloning procedures. LB and M9 [11] agar plates were used for bacteria incubation. Antibiotics were added to LB agar when appropriate (mg/ml): ampicillin - 50; tetracycline - 30; streptomycin - 100; chloramphenicol - 50, rifampicin - 100, kanamycin -100 .

Re-inoculation of onions by isolates. Onion seeds and bulbs of cvs Dencity, Chalcedon, Tamara, Volodymyr, Sterling provided by R\&D Selection Station Agrosvit (Nova Kakhovka, Kherson region). In pathogenicity tests, inoculations of inner slices from symptomless bulbs with a bacterial suspension of $\log 6$ or with a sterile $0.9 \% \mathrm{NaCl}$ solution were performed at room temperature. Necrosis of plant tissue was registered after 24, 48 and $72 \mathrm{~h}$. The characterized onion-derived isolate IMBG291 was introduced into greenhousegrown onion plants by bulb inoculation. The suspension of $\log 6 \mathrm{CFU} / \mathrm{ml}$ was used for dipping bulbs for few seconds.
Bacterization of Arabidopsis thaliana L. Heyhn Col-0 (Cold Spring Harbor, USA), onion, and lettuce (Lactuca sativa) (National Botanical Garden NAS of Ukraine) with the isolate was performed by a spray of vegetation with the suspension of $\log 6 \mathrm{CFU} / \mathrm{ml}$.

Total bacterial DNA was isolated from $1.5 \mathrm{ml}$ overnight culture according to protocol recommended by MoBio Laboratories, Inc. (USA).

Plasmid bacterial DNA was isolated from $1.5 \mathrm{ml}$ overnight culture as recommended by [12].

PCR development. Primers a79F and a79R [13], and primers YV1 and YV4, which were designed from the $16 \mathrm{~S}$ rRNA gene region of the $S$. marcescens genome [14], pA and pH described by [10] were used in a PCR. Bacteria grown in broth were washed once with $0.5 \mathrm{M} \mathrm{NaCl}$, re-suspended in distilled water, and $1 \mu \mathrm{l}$ suspension was used as a template. A PCR performed with the T-Cy PCR System (CreaCon Technologies, The Netherlands) was carried out in a $25-\mu l$ volume including $5 \mu \mathrm{l}$ of $5 \times$ buffer, $0.5 \mathrm{mM}$ of deoxynucleoside triphosphate (dNTP), $0.1 \mu \mathrm{M}$ of each primer and $2 \mathrm{U}$ of Taq DNA polymerase. PCR conditions were as follows: 1 initial denaturation cycle at $95{ }^{\circ} \mathrm{C}$ for $5 \mathrm{~min}$, followed by 34 cycles of $94{ }^{\circ} \mathrm{C}$ for $40 \mathrm{~s}, 60{ }^{\circ} \mathrm{C}$ for $1 \mathrm{~min}, 72^{\circ} \mathrm{C}$ for $1 \mathrm{~min} 30 \mathrm{~s}$, and 1 final extension cycle of $72{ }^{\circ} \mathrm{C}$ for $7 \mathrm{~min}$.

DNA sequencing and analysis were done as described earlier [15].

Total DNA isolation from onion and its analysis. Total DNA isolation from inner healthy or decayed onion bulb leaves was performed aseptically with UltraClean $^{\mathrm{TM}}$ Plant DNA isolation kit (MoBio Laboratories, Inc.). Isolated DNA was subjected to a specific PCR (primers YV1 and YV4) and 16S-PCR/TRFLP analyses.

Terminally-labeled Restriction Fragment Length Polymorphism (TRFLP) analysis of onion bulb tissue endophytic populations was performed by a method described earlier [16].

Detection of integrons and gene cassettes in pure cultures of serratia with primers to conserved sequences used were HS298 and HS286 (these primers target intI and the attC), HS287 and HS286 (target a 59-be) $[17,18]$, CS (target the flanking regions of 59-be sites) [19], qacE $\Delta 1-\mathrm{F}, \mathrm{R}(q a c \mathrm{E} \Delta 1)$ and sul1F, R (bla ${ }_{\mathrm{IMP}}$ and 3'CS) [20]. Reaction mixes consisted of approximately 1 


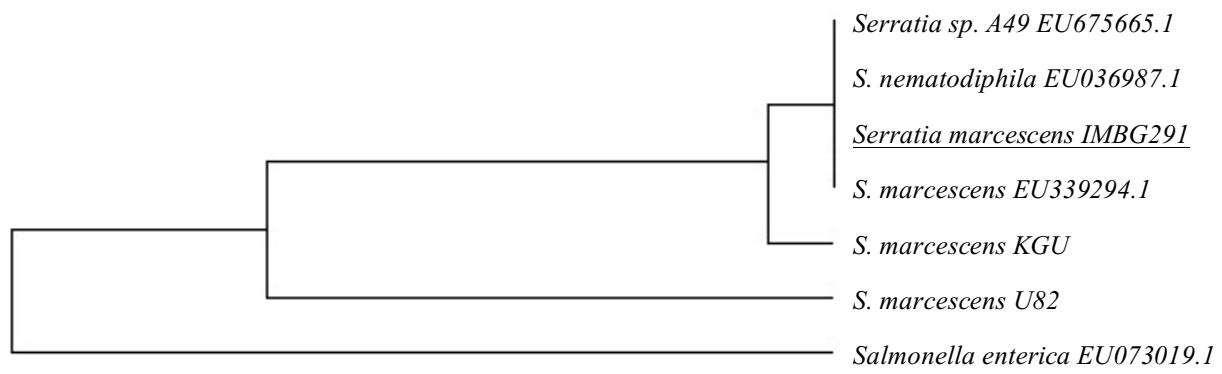

Fig. 1. Phylogenetic position of the Serratia marcescens. IMBG291, isolated from a decayed onion. The $16 \mathrm{~S}$ rDNA sequences of the isolate, Salmonella enterica (outgroup), S. nematodiphila [45] and type strains of the Serratia genus were retrieved from Ribosomal Database Project (RDP) [7] and aligned by using ClustalW [40] and Mega 4 [18]
Fl of culture, 100 pmol of each primer, $200 \mathrm{nM}$ dNTP mix, $2 \mathrm{mM} \mathrm{MgCl}_{2}$, and $1 \mathrm{U}$ of Taq DNA-polymerase («Fermentas», Lithuania) in the reaction buffer supplied with the enzyme. PCR was carried out by standard techniques with the cycling program $[17,18]$.

Nucleotide sequence accession number. The $16 \mathrm{~S}$ rRNA gene sequence was deposited in GenBank (NCBI, USA), and given accession number was FJ263679.

Results. Isolation and identification of onion-derived pathogens. The isolate IMBG291 originates from internal decaying leaf bases of naturally infected onion bulbs, however, it was not isolated from seeds and symptomless bulb tissue. The isolate was pathogenic to onion (cv. Density) bulb tissue in re-inoculation experiments at 28 and $40{ }^{\circ} \mathrm{C}$, and a level of bacteria aggressiveness was higher at the elevated temperature. After numerous passages, pathogenicity potencial of the isolate was not exhausted. The onion-derived isolate culture, introduced into aseptically grown Arabidopsis plants, in greenhouse-grown onion and lettuce plants by leaves and bulb inoculation, did not show signs of infection. The onion bulbs inoculation, seed bacterization of Arabidopsis, onion, and lettuce with the isolate significantly enhanced plant biomass (data not shown).

The isolate exhibited multiple antibiotics resistance, and apparently the determinants encoding these resistances were located on the bacterial chromosome because no plasmid DNA had been detected. PCR was carried out to demonstrate relatedness of the isolate IMBG291 to pathogenic or non-pathogenic Serratia. Using species-specific primers YV1 and YV4, a 409bp amplicon was derived from $S$. marcescens strains, used as reference, and the onion isolate. No fragments were amplified from non-S. marcescens strain E. coli
DH5 $\alpha$ (data not shown). Primers designed by [13] based on one Z01-A-specific sequence, A79, were used in a PCR to discriminate between $S$. marcescens strains caused cucurbit yellow vine disease and the isolate IMBG291.

No PCR products were generated in the experiment that showed no specific sequence similarities between two specific pathogens.

Comparison of a specific sequence of the rrs gene with sequences deposited to GenBank and RDPII suggested that the IMBG291 isolate belong to the Serratia genus, having the highest homology to $S$. marcescens (99\%). The isolate revealed also a high homology of the $r r s$ gene of $S$. nematodiphila (98\%). The Institute collection N 291 has been given to the isolate. When a phylogenetic tree was constructed from the type strains of the Serratia genus (Fig. 1), the isolate IMBG291 formed a cluster with $S$. marcescens EU339294.1 and S. nematodiphilia EU036987.1.

Determination of Serratia-related rDNA in total onion DNA isolated from healthy and decayed inner tissues. The objective was to detect $S$. marcescens DNA within a pool of total DNA isolated from healthy onion samples because of putative unculturability of the bacterium, happened with bacteria in a plant tissue. DNA isolated from six onion cultivars (bulb petals, seeds) were subjected to TRFLP, as well as DNA isolated from decayed onion and DNA isolated from $S$. marcescens IMBG291 overnight culture. Previous in silico analysis of the virtual rrs fragment of a 507-1384 bp of S. marcescens IMBG291 (FJ263679, GenBank) showed that the endonuclease TaqI produced terminal restriction fragment of $318 \mathrm{bp}$. We have not detected $S$. marcescens rDNA in total DNA isolated from healthy onion samples with a specific PCR or $16 \mathrm{~S}$ 


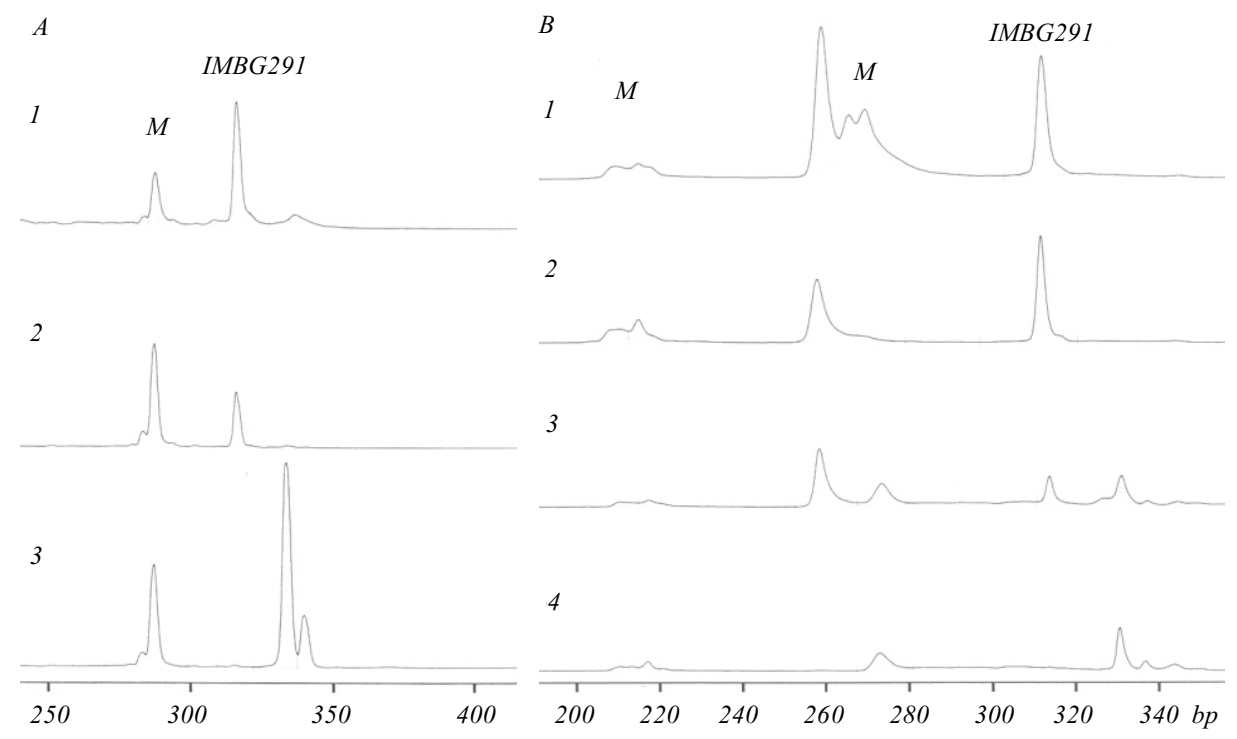

Fig. 2. Results of the TRFLP-analysis: $A$-genomic $S$. marcescens IMBG291 DNA (1); total decayed onion DNA (2); total healthy onion DNA (3); $B$ - total decayed onion DNA with added genomic $S$. marcescens IMBG291 DNA (1); total decayed onion DNA (2); total healthy onion DNA with added genomic $S$. marcescens IMBG291 DNA (3); total healthy onion DNA (4). $M$ - size marker; IMBG291- $S$. marcescens IMBG291

rRNA-PCR/ TRFLP (Fig. 2, A). Analysis revealed a significant increase a specific bacterial rDNA TRFpeak of nearly 318 bp within total DNA isolated from infected onion in response to addition of the $S$. marcescens specific TRF (Fig. 2, B).

Detection of mobile genetic elements in initial onion isolates, isolate cultured on agar within a long time, and in re-isolate. The apparent lack of plasmids in $S$. marcescens IMBG291 strain suggested that the genes encoding antibiotics resistance were located on the chromosome and may be acquired by mobile genetic elements transfer. Integron PCR experiments targeted the intI and the proximal gene of cassettes identified a fragment of putative integron class 1 (Fig. 3). This is the first report of detecting integron sequences in the phytopathogenic serratia. The variable region of the integron was determined to be 2600 bp by PCR with primers specific for the variable region between the 5'-CS conserved sequence and the 3'-CS (Fig. 3). The class 1 integron sequences were approved with specifically amplified qacE $\Delta 1$ and sul1 genes.

To identify the gene cassettes harbored in this integron, PCR amplicons were cloned into the vector pJET1/blunt and sequenced. Sequencing a 550 and a 650 PCR products confirmed that these included a 59-be sequence and showed that the cassettes carried the promoterless genes, encoding formiminoglutamate deiminase, hydrolase that takes part in histidine metabolism [21], and ascorbate-specific phosphotransferase system (PTS) enzyme IIC, inner membrane protein
[22], respectively. Other cassettes were represented with additional three senseless noncoding sequences flanked by a 59-be.

Discussion. Among the genus Serratia species, $S$. marcescens is an important bacterium reported to promote growth of agronomically valuable plants [23]. On the other hand, it is known as opportunistic human pathogen which colonizes medical instruments due to a biofilm formation and spread in clinical wards.

The isolated from onion pathogenic bacterium $S$. marcescens IMBG291 exhibited some peculiarities. First of all, this bacterium demonstrated both phytopathogenic and plant growth promotion activities in the same ecological niche (onion), depending on environmental factors. A reason for the bacterium to become pathogenic for field-grown onions remains unclear yet, but it is not excluded that a pathogenic phenotype was provoked with an elevated season temperature. The pathogenicity process is regulated with the environmental stimuli and probably with mobile genetic elements.

The onion-derived bacterium has got a mobile genetic element, the integron. Integrons and their associated gene cassettes are present in $\sim 10 \%$ of bacteria [24]. Integrons are genetic elements that play a role in the rearrangement of genes via site-specific recombination of the gene cassettes, and the first integrons were discovered as a result of investigations into the phenomenon of multiple antimicrobial agents resistance. Integrons are often located in plasmids or transposons, thus enabling the rapid spread of the gene cassettes among a wide 


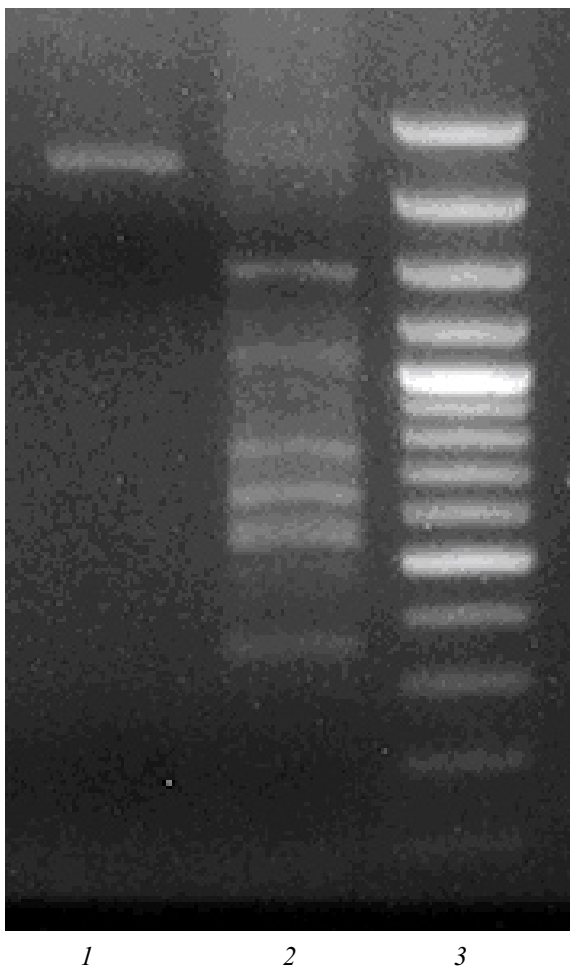

Fig. 3. Electrophoresis of PCR products generated with primers specific for int I (CS [21] (1) and for gene cassettes (HS286, HS287 [35]) (2). Molecular marker (3000, 2000, 1500, 1200, 1031, 900, $800,700,600,500,400,300,200,100 \mathrm{bp}$; «Fermentas», Lithuania) (3)

variety of bacterial species. The clinical isolates of $S$. marcescens were shown to harbor integrons on conjugative plasmids $[2,10,20,25]$. Class 1 integrons are predominant among integrons that carry resistance cassettes. The isolate from onion $S$. marcescens IMBG291 identified as plasmidless, and the integron is located on the bacterial chromosome or it is an element of a genomic island.

The gene cassettes are mobile elements typically composed of promoterless structural gene/s and a recombination site known as a 59-base element or attC site $[18,26]$. They form a variable part of integron, and stability of the latter depends on the environmental conditions. The gene cassettes of onion-derived bacterium have been represented in the integron with two promoterless genes and with additional three senseless noncoding sequences flanked by a 59-be. The coding sequences were genes encoding formiminoglutamate deiminase, hydrolase that takes part in histidine metabolism [27], and the inner membrane protein IIC, en- zyme of ascorbate-specific phosphotransferase system. The fact that encoded desintegrating enzyme occurs in the gene cassettes indicates that the onion isolate could has got the additional possibility for better utilization of both carbon and energy sources and accommodation in the environment. This gene, encoding formiminoglutamate deiminase, has also annotated in Serratia proteamaculans CP000826.1 genome [28]. The enzyme IIC functions with other transferases to allow phosphoryl transfer from HPr(his- P) to L-ascorbate via the PTS [41]. If synthesis of the carbapenem is dependent on ascorbate, the enzyme IIC may participate in synthesis of antibiotics, and so far to bring the advantage for the bacterium in the particular econiche. The PTS enzyme IIC also annotated in S. proteamaculans, Lactobacillus plantarum WCFS1 in $13^{\text {th }}$ genomic island (GI); Geobacillus kaustophilus HTA426 - in $19^{\text {th }}$ GI, and in Bacillus clausii KSM-K16 [29]. The noncoding cassettes had no significant BLASTN hits and had not been reported before. Noncoding cassettes were reported in vibrios and pseudomonads earlier [30, 31], but the details of their structures were not analyzed. We conclude that the isolate exhibited polybiotrophy because of acquired new gene cassettes located in integron which provided the additional possibility for utilization of wider spectrum of both carbon and energy sources and so far adaptation to a specific lifestyle.

\section{Л. П. Овчаренко, Т. М. Вознюк, І. С. Заєиь, А. І. Потопальський, О. Рева, Н. О. Козировська}

Мобільний генетичний елемент Serratia marcescens, збудника хвороби цибулі

\section{Резюме}

Мета. Перевірити наявність мобільних генетичних елементів (МГЕ) у бактерії, що яка спричиняє гниття вирощеної за польових умов ичибулі, та вивчити інтегрон разом з асоційованими з ним касетами генів. Методи. Полімеразна ланиюгова реакція (ПЛР) та секвенування продуктів ПЛР використано для ідентифікаиії бактерії та МГЕ. Метод аналізу поліморфізму довжини термінально мічених рестрикиійних фрагментів ПЛР-продуктів застосовано для визначення ізольованої бактерії у тканинах ичибулин. Результати. Аналізуючи послідовності нуклеотидів гена $16 \mathrm{~S}$ рРНК ізоляту з гнилої иибулі, зроблено висновок про те, що бактерія належить до виду S. marcescens, відомого фітопатогену. Проте цей ізолят не реагував на специфічні праймери, характерні для фітопатогенних сеpaтій. Інокулювання иибулі (Allium сера L.), Arabidopsis thaliana (L.) Неyhn та салату (Lactuca sativa) призвело до зростання біомаси рослин без проявів симптомів захворювання. Інтегрон першого класу виявлено за допомогою ПЛР у геномі фітопато- 
генної S. marcescens вперше. Касети генів, які містили інтегрон, представлені безпромоторними генами, що кодують форміміноглутаматдеіміназу та фермент IIC аскорбатфосфотрансферазної системи, а також трьома некодуючими послідовностями, фланковами 59-n. н.-елементом. Висновки. S. marcescens IMBG291 проявляє патогенні властивості або стимулює розвиток рослини залежно від екологічної ситуації, завдяки горизонтально набутим генним касетам, розташованим на інтегроні.

Ключові слова: Serratia marcescens, гниття ичибулі, інтегрон, генні касети

Л. П. Овчаренко, Т. Н. Вознюк, И. Е. Заец, А. И. Потопальский, О. Рева, Н. Козыровская

Мобильный генетический элемент Serratia marcescens, возбудителя заболевания лука

Резюме

Цель. Проверить наявность мобильных генетических элементов (МГЭ) у бактерии, вызывающей гниль выращенного в полевых условиях лука, и изучеить интегрон вместе с ассоииированными с ним кассетами генов. Методы. Полимеразная иепная реакция (ПЦР) и секвенирование продуктов ПЦР использовали для идентификации бактерии и МГЭ. Метод анализа полиморфизма длины терминально-меченних рестрикционных фрагментов ПЦР-продуктов применен для определения изолированой бактерии в тканях луковиц. Результаты. Анализируя последовности нуклеотидов гена $16 S$ рРНК изолята с гнилого лука, сделано вывод о том, что бактерия принадлежит к виду S. marcescens, известного фитопатогена. Однако этот изолят не реагировал на специфеские праймеры, характерные для фитопатогенных сератий. Инокулирование лука (Allium сера L.), Arabidopsis thaliana (L.) Heyhn и caлата (Lactuca sativa) приводило к возрастанию биомассы растений без проявления симптомов болезни. Интегрон первого класса выявлен с помощью ПЦР в геноме фитопатогенной S. marcescens впервые. Кассеты генов интегрона представлены беспромоторными генами, кодируюшими формиминоглутамат деиминазу и фермент IIC аскорбатфосфотрансферазной системы, а также тремя некодирующими последовностями, фланкированными 59-n. н.-элементом. Выводы. S. marcescens IMBG291 проявляет патогенные свойства или стимулирует развитие растения в зависимости от экологической ситуации, благодаря горизонтально приобретенным генным кассетам, расположенным на интегроне.

Ключевые слова: Serratia marcescens, болезнь лука, интегрон, генные кассеты

\section{REFERENCES}

1. Cother E. J., Dowling V. Bacteria associated with internal breakdown of onion bulbs and their possible role in disease expression // Plant Pathol.-1986.-35, N 3.-P. 329-336.

2. Yum J. H., Yong D., Lee K., Kim H. S., Chong Y. A new integron carrying VIM-2 metallo-beta-lactamase gene cassette in a Serratia marcescens isolate // Diagn. Microbiol. Infect. Dis.-2002.-42, N 3.-P. 217-219.

3. Edwards U., Rogal T., Bloecker M., Boettger E. C. Isolation and direct complete nucleotide determination of entire genes. Characterization of a gene coding for $16 \mathrm{~S}$ ribosomal RNA // Nucl. Acids Res.-1989.-17, N 19.-P. 7843-7853.
4. Kurz C. L., Chauvet S., Andres E., Aurouze M., Vallet I., Michel G. P., Uh M., Celli J., Filloux A., De Bentzmann S., Steinmetz I., Hoffmann J. A., Finlay B. B., Gorvel J. P., Ferrandon D., Ewbank J. J. Virulence factors of the human opportunistic pathogen Serratia marcescens identified by in vivo screening // EMBO J.-2003.-22, N 7.-P. 1451-1460.

5. Ryu C. M., Murphy J. F., Mysore K. S., Kloepper J. W. Plant growth-promoting rhizobacteria systemically protect Arabidopsis thaliana against Cucumber mosaic virus by a salicylic acid and NPR1-independent and jasmonic acid-dependent signaling pathway // Plant J.-2004.-39, N 3.-P. 381-392.

6. Selvakumar G., Mohan M., Kundu S., Gupta A. D., Joshi P., Nazim S., Gupta H. S. Cold tolerance and plant growth promotion potential of Serratia marcescens strain SRM (MTCC 8708 ) isolated from flowers of summer squash (Cucurbita реро) // Lett. Appl. Microbiol.-2008.-46, N 2.-P. 171-175.

7. Pair S. D., Bruton B. D., Mitchell F., Fletcher J., Wayadande A., Melcher $U$. Overwintering squash bugs harbor and transmit the causal agent of cucurbit yellow vine disease // J. Econ. Entomol.-2004.-97, N 1.-P. 74-78.

8. Bruton B. D., Mitchell F., Fletcher J., Pair S. D., Wayadande A., Melcher U., Brady J., Bextine B., Popham T. W. Serratia marcescens, a phloem-colonizing, squash bug-transmitted bacterium: causal agent of cucurbit yellow vine disease // Plant Dis.-2003.-87.-P. 937-944.

9. Acar J. F. Serratia marcescens infections // Infect. Control.1986.-7, N 5.-P. 273-278.

10. Crowley D., Cryan B., Lucey B. First detection of a class 2 integron among clinical isolates of Serratia marcescens // Br. J. Biomed. Sci.-2008.-65, N 2.-P. 86-89.

11. Miller J. H. Experiments in molecular genetics.-New York: Cold Spring Harbor Lab. Publ., 1972.-436 p.

12. LeBlanc D. J., Lee L. N. Rapid screening procedure for detection of plasmids in streptococci // J. Bacteriol.-1979.- 140, N 3.-P. 1112-1115.

13. Zhang Q., Melcher U., Zhou L., Najar F. Z., Roe B. A., Fletcher $J$. Genomic comparison of plant pathogenic and nonpathogenic Serratia marcescens strains by suppressive subtractive hybridization // Appl. Environ. Microbiol.-2005.-71, N 12.-P. 7716-7723.

14. Melcher U., Mitchell F., Fletcher J., Bruton B. New primer sets distinguish the cucurbit yellow vine bacterium from an insect endosymbiont // Phytopathology.-1999.-89, suppl.P. 95-99.

15. Podolich O., Laschevskyy V., Ovcharenko L., Kozyrovska N., Pirttila A. M. Methylobacterium sp. resides in unculturable state in potato tissues in vitro and becomes culturable after induction by Pseudomonas fluorescens IMGB163 // J. Appl. Microbiol.-2009-106, N 3.-P. 728-737.

16. Liu W. T., Marsh T. L., Cheng H., Forney L. J. Characterization of microbial diversity by determining terminal restriction fragment length polymorphisms of genes encoding $16 \mathrm{~S}$ rRNA // Appl. Environ. Microbiol--1997.-63, N 11.P. 4516-4522.

17. Nield B. S., Holmes A. J., Gillings M. R., Recchia G. D., Mabbutt B. C., Nevalainen K. M. H., Stokes H. W. Recovery of new integron classes from environmental DNA // FEMS Microbiol. Lett.-2001.-195, N 1.-P. 59-65.

18. Stokes H. W., Holmes A. J., Nield B. S., Holley M. P., Nevalainen K. M. H., Mabbutt B. C., Gillings M. R. Gene cassette PCR: sequence-independent recovery of entire genes from environmental DNA // Appl. Environ. Microbiol.-2001.-67, N 11.-P. 5240-5246. 
19. Levesque C., Piche L., Larose C., Roy P. H. PCR mapping of integrons reveals several novel combinations of resistance genes // Antimicrob. Agents Chemother.-1995.-39, N 1.P. 185-191.

20. Hu Z., Zhao W. H. Identification of plasmid- and integronborne blaIMP-1 and blaIMP-10 in clinical isolates of Serratia marcescens // J. Med. Microbiol.-2009.-58, pt 2.-P. $217-$ 221.

21. Marth-Arbona R., Xu C., Steele S., Weeks A., Kuty G. F., Seibert C. M., Raushel F. M. Annotating enzymes of unknown function: $\mathrm{N}$-formimino-L-glutamate deiminase is a member of the amidohydrolase superfamily // Biochemistry.-2006.45, N 7.-P. 1997-2005.

22. Yew W., Gerlt J. Utilization of L-ascorbate by Escherichia coli $\mathrm{K}-12$ : assignments of functions to products of the yjf-sga and yia-sgb operons // J. Bacteriol.-2002.-184, N 1.-P. 302306.

23. Gyaneshwar P., James E. K., Mathan N., Reddy P. M., Reinhold-Hurek B., Ladha E. K. Endophytic colonization of rice by a diazotrophic strain of Serratia marcescens // J. Bacteriol.-2001.-183, N 8.-P. 2634-2645.

24. Joss M., Koenig J., Labbate M., Polz M., Gillings M., Stokes H., Doolittle W., Boucher Y. ACID: annotation of cassette and integron data // BMC Bioinformatics.-2009.-10.-P. 118124.

25. Peng C.-F., Lee M.-F., Fu H.-T., Chen Y.-J., Hsu H.-J. Characterization of class 1 integrons and antimicrobial resistance in CTX-M-3-producing Serrratia marcescens isolates from Southern Taiwan // Jpn. J. Infect. Dis.-2007.-60, N 5.P. 250-256.
26. Recchia G. D., Hall R. M. Origins of the mobile gene cassettes found in integrons // Trends Microbiol.-1997.-5, N 10.P. 389-394.

27. Hu L., Phillips A. T. Organization and multiple regulation of histidine utilization genes in Pseudomonas putida // J. Bacteriol.-1988.-170, N 9.-P. 4272-4279.

28. Taghavi S., Garafola C., Monchy S., Newman L., Hoffman A., Weyens N., Barac T., Vangronsveld J., van der Lelie D. Genome survey and characterization of endophytic bacteria exhibiting a beneficial effect on growth and development of poplar trees // Appl. Environ. Microbiol.-2009.-75, N 3.P. 748-757.

29. Kleerebezem M., Boekhorst J., van Kranenburg R., Molenaar D., Kuipers O. P., Leer R., Tarchini R., Peters S. A., Sandbrink H. M., Fiers M. W., Stiekema W., Lankhorst R. M., Bron P. A., Hoffer S. M., Groot M. N., Kerkhoven R., de Vries M., Ursing B., de Vos W. M., Siezen R. J. Complete genome sequence of Lactobacillus plantarum WCFS1 // Proc Nat. Acad. Sci. USA.-2003.-100, N 4.-P. 1990-1995.

30. Boucher Y., Nesbo C. L., Joss M. J., Robinson A., Mabbutt B. C., Gillings M. R., Doolittle W. F., Stokes H. W. Recovery and evolutionary analysis of complete integron gene cassette arrays from Vibrio // BMC Evol. Biol.-2006.-6.-P. 3-8.

31. Li X., Shi L., Yang W., Li L., Yamasaki Sh. New array of aacA4-catB3-dfrAl gene cassettes and a noncoding cassette from a class-1-integron-positive clinical strain of Pseudomonas aeruginosa // Antimicrob. Agents Chemother.-2006.50, N 6.-P. 2278-2279. 